\title{
The implementation of spatial management as a factor supporting flood protection
}

\author{
Elżbieta Jasińska ${ }^{1, *}$ \\ ${ }^{1}$ AGH University of Science and Technology in Kraków, Faculty of Mining Surveying and Environmental Engineering, \\ Department of Geomatics, al. Mickiewicza 30, 30-059 Kraków, Poland
}

\begin{abstract}
This publication presents the issues related to cadastre and real estate management in flood protection. Cadastral data supported by other additional data is the basis for taking action in situations of natural hazards. A real estate cadastre is an important element in the implementation of a real estate acquisition plan. It allows for preliminary assessment of the negative impact of the project, change of the concept and, as a result, expropriation and compensation regulation. In parallel with the activities related to the acquisition of real estate, it is possible to regulate the legal status of other properties. In this publication, the analysis is based on the document entitled "Plan of obtaining real estate and resettlement for the Flood Protection Project in the Odra and Vistula basin, Component 3B: Protection against Sandomierz flood and Tarnobrzeg, Contract 3B.3, flood protection Tarnobrzeg - stage 1 (Wisła 1) ". This area is the research material of actions changing the forms of land management in order to increase the safety of areas exposed to floods. The effects of carrying out this project were an important part of the work, including restrictions in the use, loss of real estate. The implementation of a flood protection project may have a negative impact on the economic status of people living in the areas where the activities were planned. These may be restrictions on the use of real estate, in particular the loss of a part or the whole of the property as a result of expropriation. Ultimately, such actions may result in the resettlement of residents. As a part of the study, the compensation for particular entities was described in detail. The results of surveys confirming the lack of a negative impact on the economic situation of people affected by the project implementation were presented.
\end{abstract}

\section{Introduction}

Crisis management consists of activities aimed at eliminating the occurrence of natural hazards, ie floods, landslides and anticipating the possible effects of these phenomena. In order to prevent damages to the water banks, actions are taken, such as modernization of flood embankments or construction of new elements of hydrotechnical infrastructure. The next stage of forecasting the possible effects of threats consists mainly in the preparation of safeguards, for example the creation of a landslide record database. [1]

The crisis management process is currently supported mainly by cadastral data. Thanks to them, spatial recognition of the area, taking into account the threats related to floods is possible. In addition, it is possible to analyze the area in terms of its state of ownership and use. $[2,3,4]$

Along with the development of civilization, the number of occurrences of natural hazards also increased. Preparation of services and adequate and effective organization are necessary to prevent the danger associated with floods. Thanks to crisis management, it is possible to respond as quickly as possible by government and local government administration units.
A real estate cadastre is an official register that contains information about the actual state of ownership. Thanks to these data, it is possible to properly manage that area. They are the basis for infrastructure management, spatial planning or issuing administrative decisions. Cadastral data supported by other additional data is the basis for taking action in situations of natural hazards. $[5,6,7]$.

Article 112 of the Water Law Act [8] specifies planning in water management, the purpose of which is to design and harmonize activities to maintain good water status and dependent ecosystems. It is also important to ensure better condition of water resources and increase the possibility of using water reservoirs. The substances and energy introduced into them may have a negative impact on the water, therefore it is necessary to eliminate this risk by reducing their quantity. Another very important goal is control and progress in flood protection.

\section{Preparation of the investment}

Act of 8 July 2010 on special rules of preparation for the implementation of investments in the scope of flood protection structures [9] defines several stages of implementation of the project implementation process. The decision on the implementation of the investment is

$\overline{\text { *Corresponding author: jasinska@agh.edu.pl }}$ 
made by the voivode, whose area is the larger part of the investment, in the case in which this area includes two or more voivodships. In order for the investor to receive approval, he must submit an application to the voivode. The voivode immediately notifies the higher-level authority (minister competent for construction, planning and spatial development and housing) about the receipt of the application and its issuance. In order for the application to be considered by the voivode, it must contain the necessary elements, among others: the location of the investment and its characteristics, technical parameters, a map with a scale of not less than 1: 10000, maps of projected property divisions, relevant opinions [10].

In order for the investment to be carried out, it is necessary to regulate the legal status of the real estate in which the hydrotechnical construction site is to be constructed. When the proceedings in the matter of the decision on the consent for making the investment are initiated, the voivode is obliged to notify the applicant, the owner or perpetual usufructuary of the real estate for which the application applies, and the voivods in whose area the planned investment is located. An exceptional case is a property whose legal status is not unregulated. The voivode sends a notification only to the applicant. Any interested person may become familiar with the files of the case within the prescribed time and place.

The decision on the investment permit includes primarily information on the scope of the land delimitation. It is important to implement the project to determine the conditions for environmental protection and monuments. The decision may not contradict the state defence conditions and the interests of third parties. The components of the decision on the permission for the investment are confirmation of the division of the property. This decision is issued up to 90 days from the moment the investor submits this application. The real estate cadastre defines two types of real estate. The first ones are those owned by the State Treasury or local government units. The other shall not be subject to the ownership of the State Treasury or local government units. In the local press, on the websites of the voivodship office and the communes where the investment is to be implemented, the voivode's announcement regarding the consent for the investment is issued. The decision is delivered to the applicant, while the notification of the decision is sent to the persons who were the current owners or perpetual usufructs of the real estate. The party can appeal against the decision, while the appeal is reviewed within 30 days.

The effect of issuing the decision on the permission to implement the investment is to approve the division of the property. Their division is defined by lines delimiting the area, which are designated in the decision. The next consequence is entries in the land and mortgage registers and real estate cadastre. Everybody who is the owner or perpetual usufructuary of a real estate whose ownership has passed to the State Treasury or a local government unit is entitled to compensation. The right to perpetual usufruct expires in the case of real estate owned by the State Treasury or local government units transferred in the past to use after the decision.
The investor has the option to buy real estate that is outside the investment area. The purchase is aimed at exchanging real estate for those located in the area of the planned investment. The investor also has the option of separating them in merger-exchange proceedings. The real estate or part of the real estate is taken over by the State Treasury or a local government unit, because it is necessary for the implementation of the flood protection investment. The part that is not taken over must be suitable for proper use. If this is not the case, the investor must acquire this part of the property for the benefit of the Treasury or a local government unit. The right to take possession of the real property takes place within 90 days of the decision on consent for the investment. Within this period, the people who live in the property must leave it because the voivode gives the decision immediate enforceability. However, the investor has to indicate replacement rooms within this period. An exception is the situation in which the actual taking possession of the property takes place after the expiration of the set time limit. Then the investor does not have to indicate a replacement property. An investor can be an organizational unit that does not have legal personality or voivodship marshal. He must carry out activities for and on behalf of the Treasury in the field of government administration. The investor receives real estate owned by the State Treasury in permanent management.

\section{Analysis area}

The analytical example was the activities carried out under the Contract 3B.3, flood protection Tarnobrzeg stage 1 (Wisła 1). This document is one of the three Contracts: Real estate acquisition plan and displacement for the Flood Protection Project in the Odra and Vistula basin, Component 3B: Protection against floods in Sandomierz and Tarnobrzeg.

The main objective of the Plan of Acquisition of Real Estate and Resettlement is effective protection against extreme floods of towns located in the basins of two rivers: Vistula and Odra. It presents a protection plan for two towns: Sandomierz and Tarnobrzeg. The protection of Tarnobrzeg consists mainly in securing 4,100 buildings, about 80 enterprises, the Huta Szkła and the historic Dominican Monastery Church. [11]

Indeed, Contract 3B.3 covers the city of Tarnobrzeg, but it exits the framework of the regional project, as it also allows the protection of the right bank of Sandomierz. The area covered by the Contract is a $9.9 \mathrm{~km}$ section, 255,000$264.760 \mathrm{~km}$ in the Vistula's kilometre (Figure 2). The contract covers the city of Tarnobrzeg, to the territories bordering the Podkarpackie Voivodeship, near the city of Koćmierzów. The area of approximately 4846 ha is inhabited by 7800 inhabitants. Additionally, cubature and linear objects are subject to protection. The implementation of the contract is aimed at:

- Increasing the height of the crown of the embankment and compacting the base by $1.5-1.8 \mathrm{~m}$;

- Clogging of the drainage slope, body and base of the embankment through, among others Construction of anti-filtration cover (depth approx. $10 \mathrm{~km}$ ); 
- Establishment of new and renovation of existing service roads;

- Construction of a maintenance belt;

- Transforming over a dozen shaft journeys;

- Protection of 2 sluice locks with a diameter of 800 and $1,400 \mathrm{~mm}$ (in $\mathrm{km} 8+290$ and $12+866$ shaft), outflows of stormwater pumping station with a diameter of $812 \mathrm{~mm}$ (in $\mathrm{km} 13+840$ shaft) and sewage treatment plant with a diameter of $2 \times 1600 \mathrm{~mm}$ (in $\mathrm{km} 9+589$ shaft).

The list of planned real estate classes under the 3B.3 Contract is presented in the chart below

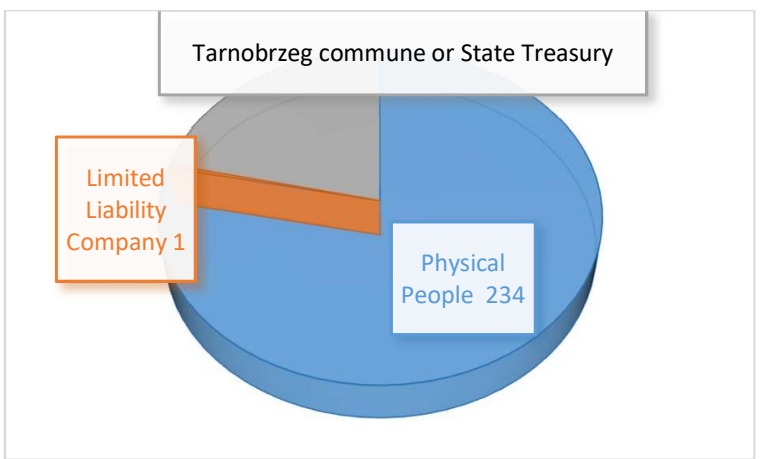

Fig. 1 Number of planned property classes

It can be seen from the chart (Figure 1) that the Plan assumes mainly the seizure of real property owned by natural persons. However, the largest group are the properties of the Tarnobrzeg Commune or the State Treasury. They occupy as much as $57 \%$ of all planned plots for occupation. Although there is only one property owned by a limited liability company, it occupies as much as $4 \%$ of the area from 299 plots of land.

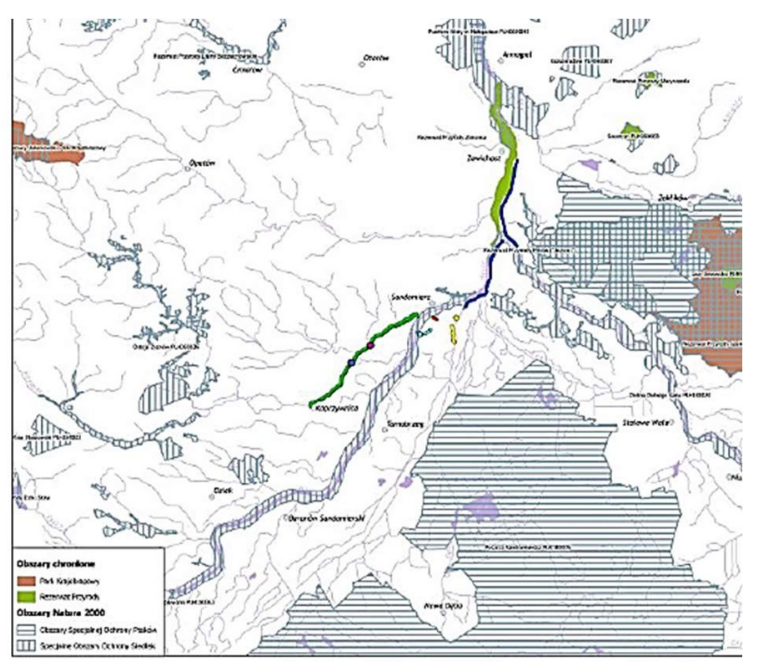

Fig. 2 Investment on the background of protected areas and Natura 2000 sites

\subsection{The effects of the project}

The Plan was intended not to cause harmful effects to society, it was based on the purchase of real estate. The physical abandonment of land by existing residents should not take place, because effective protection does not necessarily mean taking drastic steps [12].

The study presents data for the Tarnobrzeg poviat :

- from $14 / 01 / 2015$ :

- o Number of expropriated real estate / parts of real estate - 284;

○ o An expropriated area of 11,4415 ha;

- $\quad$ and from 06/05/2016:

- Number of expropriated real estate / parts of real estate - 12 ;

○ o An expropriated area with an area of 0.0894 ha;

An additional effect of the preparation for the implementation of the project was the restriction in the use of two properties. These properties were not used by anyone for agricultural purposes. The first restriction was imposed at the intersection of a public road with a flood embankment. This resulted from the temporary formation of mobile flood gates in the $15+700$ to $15+819 \mathrm{~km}$ of the embankment. This is an action to ensure future safety in the event of a flood hazard. When there is a danger, it will be necessary to limit the use of the public road and to establish a security by PZMiUW (polish abbreviation for Podkarpacki Board of Land Reclamation and Water Facilities in Rzeszów). The situation concerns plots No. 62 and No. 292. There is a rainwater channel outlet in their area.

Table 1. Real estate for which a usage restriction has been applied

\begin{tabular}{|c|c|c|c|}
\hline 光 & 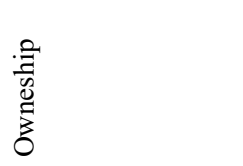 & 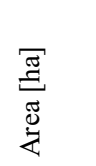 & 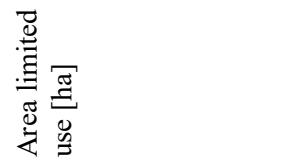 \\
\hline 62 & $\begin{array}{l}\text { State Treasury } \\
\text { (based on land and } \\
\text { building register) }\end{array}$ & 2,0141 & $\begin{array}{l}0,0640, \text { which is } \\
3,18 \% \text { of total area }\end{array}$ \\
\hline 292 & $\begin{array}{l}\text { Tarnobrzeg } \\
\text { commune } \\
\text { (according to Land } \\
\text { and Mortgage } \\
\text { Register no } \\
\text { TB1T/00075069/8) }\end{array}$ & 0,4087 & $\begin{array}{l}0,0500 \text { which is } \\
12,23 \% \text { of total area }\end{array}$ \\
\hline
\end{tabular}

In addition, based on the decision, the economic building located on one plot, owned by a natural person, was demolished.

The real estate concerned by the demolition has been temporarily occupied. In order to obtain a basis for payment of compensation to the owner, an independent appraiser was appointed. In the case of losing trees, the same steps are applied for: owners, perpetual users, selfemployed owners, users, tenants. Namely, the compensation is paid in the amount taking into account lost profits from logging and the amount of maintaining and establishing the stand. Only persons who are in illegitimate possession of the property are allowed to cut down and take trees without paying compensation [4]. 


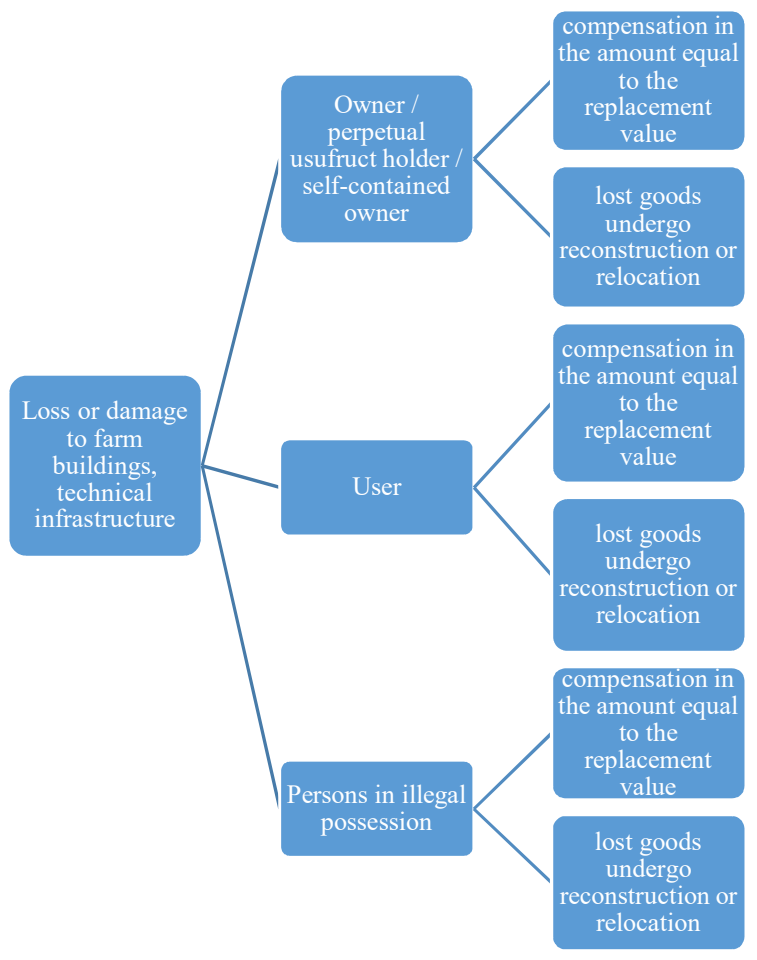

Fig. 3 Solutions for people whose outbuildings and technical infrastructure have been permanently damaged or destroyed as a result of the project

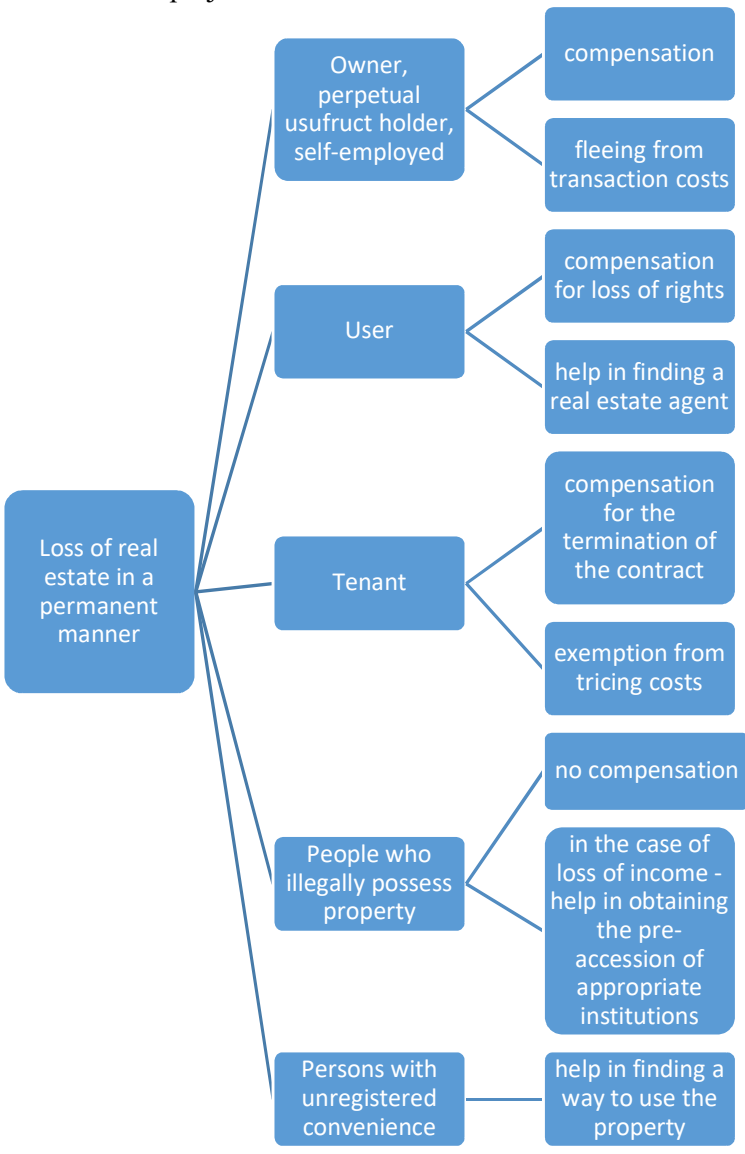

Fig. 4 Solutions for the loss of real estate in a permanent manner depending on the property right owned
Occupancy also affects the employment of entrepreneurs. In the case of companies, enterprises or non-governmental organizations, mainly compensation is applied. Losses related to municipal property are eliminated by rebuilding or replacing damaged objects. Negative effect loss of access to the infrastructure may also be possible. Reconstruction of infrastructure in another place, or when it is impossible to provide access to the existing infrastructure is a way to eliminate damages. It is also possible to provide other recreational places.

For some properties for which the payment of compensation was established, the lack of regulation of the legal status of real estate is the main obstacle to its payment. [4] In such a case, the Governor conducts proceedings to regulate the legal status. 109 properties from the 299 pool, which were included in the Plan, are intended for agricultural purposes $[7,13]$. Of these properties, only:

- 30 lost over $20 \%$ of the area.

- 10 plots reduced its area to less than 0.5 ha.

The owners received surveys aimed at determining if the occupation of a part of the property had a negative impact on their living standards. Surveys have shown that this has not resulted in a reduction in farm incomes. This is mainly due to the fact of the minimum occupation of the property. By law, owners who have left such a part of the property that is unusable may apply for the remaining part of the property.

The properties belonging to the Tarnobrzeg Commune constitute only $2 \%$ of the number of plots, but their percentage area is the largest and amounts to as much as $56 \%$. However, the area of plots owned by natural persons, permanently occupied in the number of 234, is $39 \%$ of all plots taking part in the Project. The main real estate occupied as part of the Project are: meadows, pastures, wastelands and arable lands. They constitute, in total, $87.89 \%$ of the total area of all plots seized. Thanks to this, resettlements related to the expropriation of plots previously inhabited have been minimized.

No real estate that is subject to occupation is not subject to a lease managed by the Agricultural Property Agency [14,15]. However, perpetual usufruct was disclosed for two plots of land. There are also unregulated inheritance cases for 13 properties whose owner or coowner is dead. The compensation was sent to the deposit until the heirs were determined. On 30 March 2016, decision No. 1/2016 of the Podkarpackie Voivod was issued regarding the permit for the implementation of investments in the scope of flood protection structures. On 06.05.2016, this decision became final. In connection with which 12 properties were expropriated ( 10 belonging to natural persons and 2 belonging to the Tarnobrzeg Commune). The compensation amount, determined by an independent property appraiser, amounted to PLN $1,9366.00$.

The main goal in the preparation of the project was to achieve the minimum number of permanent and temporary activities on real estate and restrictions on their use. Temporary activities are necessary to enable building 
facilities to be placed near the construction site, as well as collection of land and other materials.

The real properties that are covered by the project become the property of the State Treasury or are permanently limited in use on the day when the decision on the investment permit becomes final. After its release, it is possible to make entries in the land and mortgage register and real estate cadastre [7,13]. However, for real estates permanently limited in the manner of their use, they have the right to submit an application for the purchase of such real estate by the State Treasury. An exception are real estate where public roads are located.

\subsection{Methodology of real estate valuation to estimate the amount of compensation}

A property appraiser may apply a comparative, mixed or income approach to determine the market value of a given property. [12,16,17]

The use of real estate in the local zoning plan may increase the value. In this case, an alternative method of use is used to determine compensation.

The value of forest stand and afforestation is determined on the basis of the value of wood in a given area, if there are functional materials there. In a situation where there are no utility materials in the area or the price that can be obtained from its goods is too low, i.e. the value of the wood is smaller than the contribution (afforestation and care), this contribution is estimated to the date of expropriation. When it comes to, for example, annual collections, the estimated value of crops is calculated based on the value on the current market. The costs incurred in harvesting are deducted from this amount.

Construction objects being a separate object of property from real estate must be considered in a different way $[6,18]$. In this case, the cost approach, indicator technique or replacement cost method is used. The value of a property is assessed on the condition that it is equal to the cost of reconstruction or replacement of this property.

It is important for the cost approach to understand that the person who acquires the property is not prone to incur higher costs than the theoretical construction of the same building, in the same technology in the same place. The cost of replacement is, therefore, the cost that should be incurred to build a copy of the valued property, based on technical data of the building, prices of materials and costs related to the construction of the building. When assessing the value of the property by an expert, the following factors are taken into account [19]:

- the project;

- equipment;

- technology, materials and diligence in carrying out construction works;

- shortcomings and deficiencies;

- elements that are not necessary for the operation and construction of the facility;

- costs incurred in the construction of accompanying equipment;

- land development for construction;
- design and cost related to construction supervision;

\subsection{Socio-economic research}

To correctly determine the use and development of real estate, the data from the extract of land and building records as well as GIS data should be analysed deeply. It is also important to correctly assess the actual state of the place of implementation. However, land and mortgage registers and extracts from the land and building register provide data on landlords, perpetual usufructers and persons who have limited property rights. On the basis of MDCP ( abbreviation use in polish to name map for design purposes) and site verification, infrastructure information was received.

The National Court Register, the register of business activity registers, local intelligence within the project implementation area, statistical data obtained from the Central Statistical Office provided information on social impacts. Among the persons covered by the project, questionnaires regarding the impact on economic aspects of life and perception of the need to implement the Contract for Works 3B.3 were carried out.

In order for the survey to reflect as much as possible reality, it was addressed to people whose properties were expropriated. An additional condition was to occupy over $10 \%$ of the original real estate area. 75 people were surveyed. Replies were received from 56 people. $100 \%$ of respondents answered that the implementation of the Project had no negative impact on their income and on the quality of their lives. The applications are satisfactory because the surveys show that the implementation of the flood embankment is satisfactory for the inhabitants and this has not deteriorated their economic situation.

In the case of the Contract under discussion, there was no need to carry out detailed socio-economic studies. Typically, such surveys use questionnaires that are dedicated to specific individuals. Based on preliminary research, surveys conducted among 75 people, it was found that due to occupying only fragments of plots, physical and economic resettlements would not be necessary. The nature and location of the Contract confirm that the socio-economic costs will not be high. This is mainly due to the fact that there are no public utilities in the designated area.

\section{Conclusions}

Flood protection Tarnobrzeg- stage 1 (Wisła 1), which is one of the three Contracts for Real Estate Acquisition and Resettlement for the Odra and Vistula River Basin Flood Protection Project, Component 3B: Flood Protection Sandomierz and Tarnobrzeg. Flood protection concerned the right bank of the Vistula. The implementation of the task was supra-regional, as it also included the right bank of Sandomierz. The analysis confirmed that the implementation of the flood protection project does not negatively influenced the economic status of people living in the areas where activities were planned. These were restrictions on the use, loss of some or all of the property. 
It should be noted that plots that were expropriated were mainly used for agriculture (eg orchards, meadows). There was no need to resettle the inhabitants. A real estate cadastre is an important element when implementing a real estate acquisition plan. It allows for preliminary assessment of the negative impact of the project, change of the concept and, as a result, expropriation and compensation regulation. Under the influence of activities related to acquiring real estate, the legal status of several properties was regulated.

\section{Acknowledgement}

Publication supported by the Polish Ministry of Science and Higher Education as a part of the program of activities disseminating science from the project „Organization of the First International Science Conference - Ecological and Environmental Engineering”, 26-29 June 2018, Kraków.

This work was carried out within the statutory studies of the AGH University of Science and Technology. Faculty of Mining Surveying and Environmental Engineering. Department of Geomatics No. 11.11.150.006.

\section{References}

1. http://geoportal.pgi.gov.pl/SOPO/aplikacja

2. A. Trystuła. Kataster nieruchomości w zarządzaniu kryzysowym, Kraków 2012

3. P. Hanus, A. Pęska-Siwik \& R. Szewczyk. Computers and Electronics in Agriculture, 144, p. 9-15. (2018)

4. M. Mika, M. Siejka, P. Leń, Ż. Król . The concept of using the water cadastre databases components for the construction of multi-dimensional cadastre in Poland. Survey Review, (2016)

5. Ustawa $\mathrm{z}$ dnia 21 sierpnia 1997 r. o gospodarce nieruchomościami

6. P. Hanus, P. Benduch \& A. Pęska-Siwik. Przegląd Geodezyjny, 89/9, 6-10. (2017)

7. E. Jasińska. Land use efficiency on example of the transformation of rural properties. The 10th International Conference Environmental Engineering: selected papers: April 27-28. 2017. Vilnius. Lithuania. (2017).

8. Ustawa $\mathrm{z}$ dnia 20 lipca 2017 r. - Prawo wodne

9. Ustawa $\mathrm{z}$ dnia 8 lipca 2010 r. o szczególnych zasadach przygotowania do realizacji inwestycji $\mathrm{w}$ zakresie budowli przeciwpowodziowych

10. Ustawa $z$ dnia 26 kwietnia 2007 r. o zarządzaniu kryzysowym

11. Plan pozyskania nieruchomości i przesiedleń dla Projektu ochrony przeciwpowodziowej w dorzeczu Odry i Wisły Umowa pożyczki Nr 8524 PL Podkomponent 3B: Ochrona przed powodzią Sandomierza i Tarnobrzegu
12. P. Leń. Computers and Electronics in Agriculture 144, 216-221. (2018)

13. Rozporządzenie Rady Ministrów $\mathrm{Z}$ dnia 21 września 2004 r. w sprawie wyceny nieruchomości i sporządzania operatu szacunkowego

14. E. Jasińska, E. Infrastruktura i ekologia terenów wiejskich 1/III, p. 31-40. (2012)

15. E. Jasińska, E. Preweda. Determining the cadastraltax areas for the real estate premises based on the model of qualitative and quantitative. 10th International Conference Environmental Engineering : selected papers: April 27-28, 2017, Vilnius, Lithuania. (2017)

16. E. Jasińska. Real Estate Due Diligence On the Example of the Polish Market. 14th SGEM GeoConference on Informatics. Geoinformatics and Remote Sensing 2. SGEM2014 Conference Proceedings. June 19-25. 2014. Vol. 2. Bulgaria (2014)

17. M. Siejka, M. Mika, Methodology of inventory components of real estate for the purpose of valuation, as the process of facilitating the implementation of a public investment. 10th International Conference Environmental Engineering, April 27-28, 2017 Vilnius, Lithuania. (2017)

18. P. Hanus, P. Benduch \& A. Pęska-Siwik. Przegląd Geodezyjny 90/2, 24-27. (2018)

19. M. Siejka, M. Mika, T. Salata \& P. Leń. Algorithm of land use spatial data processing for the local flood risk mapping, Survey Review (2017) 